\title{
Politikk for bedre global helse
}

\author{
En kommisjon ledet av Universitetet i Oslo har i samarbeid med tidsskriftet The Lancet utredet hvordan \\ verdensomspennende styringssystemer for global helse kan forbedres. I rapporten oppsummeres kunnskap \\ om uakseptabelt store forskjeller $\mathrm{i}$ helse og helsetjenester mellom og innen land. Vi savner en diskusjon \\ av klimaendringenes konsekvenser for global helse og hvordan disse best kan håndteres.
}

Kommisjonen la frem sin rapport på et møte i Oslo 11.2. 2014 (1). Der slås det fast at politiske og andre maktstrukturer både på internasjonalt og nasjonalt nivå er viktige for helsetilstanden, og at ulike aktører, statlige så vel som ikke-statlige, ikke samarbeider godt.

Viktigheten av økonomiske, sosiale og politiske faktorer når det gjelder helse understrekes. Asymmetriske maktstrukturer og lite koordinerte globale styringsstrukturer er til hinder for bedring. Problemene forsterkes av svake institusjoner, sviktende demokratisk kontroll og korrupsjon.

Kommisjonen anbefaler at det må åpnes for bredere deltakelse i global styring av beslutninger som angår helse, med et perspektiv som favner flere politiske områder. Kommisjonen foreslår derfor at det etableres en «multistakeholder platform» som et forum for å synliggjøre helsevirkninger, påvirke beslutninger og foreslå bedre løsninger som fremmer global helse. Plattformen skal inkludere stater og overnasjonale maktstrukturer og organisasjoner, eksempelvis menneskerettighetsorganisasjoner, representanter for internasjonal finans og handel, internasjonale organisasjoner og sivilsamfunnet/frivillige organisasjoner.

Videre foreslås det etablering et vitenskapelig panel for å overvåke globale sosiale og politiske determinanter for helse og studere hvordan komplekse samfunnsforhold og maktstrukturer påvirker helsetilstanden.

\section{Skjevfordeling og fattigdom}

Behovet for å redusere dagens store ulikhet i ressurser, helse og helsetjenester understrekes. Horton \& Lo påpeker at det for 2014 forventes atskillig sterkere økonomisk vekst i fattige land enn i rike $(5,3 \%$ versus $2,2 \%)(2)$.

Det nevnes ikke hvor forskjellig utgangspunktet er. En vekst på $5 \%$ for et bruttonasjonalprodukt (BNP) på 600 dollar per person i Tanzania tilsvarer 30 dollar, mens en vekst på $2 \%$ av et bruttonasjonalprodukt på rundt 100000 dollar per person $\mathrm{i}$ Norge er 2000 dollar. Dette illustrerer de enorme fordelingsproblemene i verden.

\section{Klima og helse}

Rapporten tar opp den internasjonale debatten om globale mål for helse og bærekraftig utvikling og etterspør en økonomi som styres etter naturens bærekraft og menneskers helse. Klimaendringenes konsekvenser og hvordan disse kan håndteres, diskuteres imidlertid ikke. Klimaendringene er av en tidligere Lancet-kommisjon beskrevet som den største trusselen mot global helse i vårt hundreår (3). Vi må nå også snakke om planetens helse. God helse globalt i årene som kommer forutsetter forebygging av klimaendringene samtidig som fattigdomsrelaterte og andre helseskader reduseres.

En politikk for økonomisk utvikling og fattigdomsreduksjon bør derfor ses i sammenheng med en bærekraftig energiproduksjon. Fattige trenger materiell vekst. Greier vi ikke å skaffe nok fornybar energi for å sikre bedre levekår for dagens fattige, men satser på fortsatt fossilbasert vekst

\section{«Dagens ulikheter i helse er moralsk uakseptable»}

også i fattige land, vil klimaendringene snart få konsekvenser som mer enn underminerer den fremgangen vi har sett i global helse i de senere år. Som Richard Horton var inne på i sin kommentar på møtet i Oslo: Hva hjelper andre tiltak hvis planeten dør?

\section{Politisk vilje avgjørende}

Det er ikke vanskelig å slutte seg til rapportens konklusjoner, som sier at dagens ulikheter i helse er moralsk uakseptable og at globale styringsmekanismer for helse må ha solidaritet og ansvarsdeling som underliggende verdier. Spørsmålet blir om politiske ledere har interesse av å endre fordelingen av rikdom og makt og om de ønsker å kontrollere de sterke økonomiske kreftene som de multinasjonale selskapene og spesielt oljeindustrien representerer.

Horton \& Lo antyder også at det å ta vare på god helse er en stor utfordring for kapitalismen (2). Å løse problemet med stor ulikhet $i$ helse vil kreve en annen og dypere forståelse av årsakene og, ikke minst, avdekke hvordan man best kan skape nødvendig vilje til radikale endringer hos politikere verden over.

\section{Fra ord til handling}

For at kommisjonens arbeid skal føre til forbedrede styringsmekanismer for beslut- ninger som angår helse, vil det kreve at alle aktører som kommisjonen beskriver gjøres kjent med og følger opp kommisjonens anbefalinger. Det bør snarest settes ned en gruppe, helst av FNs generalsekretær, som kan starte arbeidet med å etablere plattformen som skisseres i rapporten.

Det bør etableres et nært samarbeid med FNs klimapanel og andre med kunnskap om hvordan klimaendringene skader helsen og hvordan skadene best kan forebygges. En annen Lancet-kommisjon studerer i disse dager sammenhenger mellom klima og helse. I utviklingen av «the post-2015 development agenda» er det ønskelig at resultatene fra disse to kommisjonene ses i sammenheng. Dette kan gjøre det mer sannsynlig at god og bærekraftig helse kan sikres. Helseskadene som klimaendringene alt nå bidrar til, vil gradvis øke i omfang, men kan fortsatt begrenses ved en effektiv klimapolitikk som raskt sikrer utslippsreduksjoner og nødvendig klimatilpasning.

\section{Gunnar Kvåle}

gunnar.kvale@cih.uib.no

Bente Elisabeth Moen

Gunnar Kvåle (f. 1942) er professor emeritus ved Senter for internasjonal helse, Universitetet i Bergen.

Forfatter har fylt ut ICMJE-skjemaet og oppgir ingen interessekonflikter.

Bente Elisabeth Moen (f. 1956) er professor og direktør for Senter for internasjonal helse, Universitetet i Bergen.

Forfatter har fylt ut ICMJE-skjemaet og oppgir ingen interessekonflikter.

\section{Litteratur}

1. Ottersen OP, Dasgupta J, Blouin C et al. The political origins of health inequity: prospects for change. Lancet 2014; 383: 630-67.

2. Horton R, Lo S. Protecting health: the global challenge for capitalism. Lancet 2014; 383: 577-8.

3. Costello A, Abbas M, Allen A et al. Managing the health effects of climate change. Lancet 2009; 373 1693-733.

Mottatt 6.3. 2014, første revisjon innsendt 29.3. 2014, godkjent 2.4. 2014. Redaktør: Kari Tveito.

Publisert først på nett.

Engelsk oversettelse på www.tidsskriftet.no 